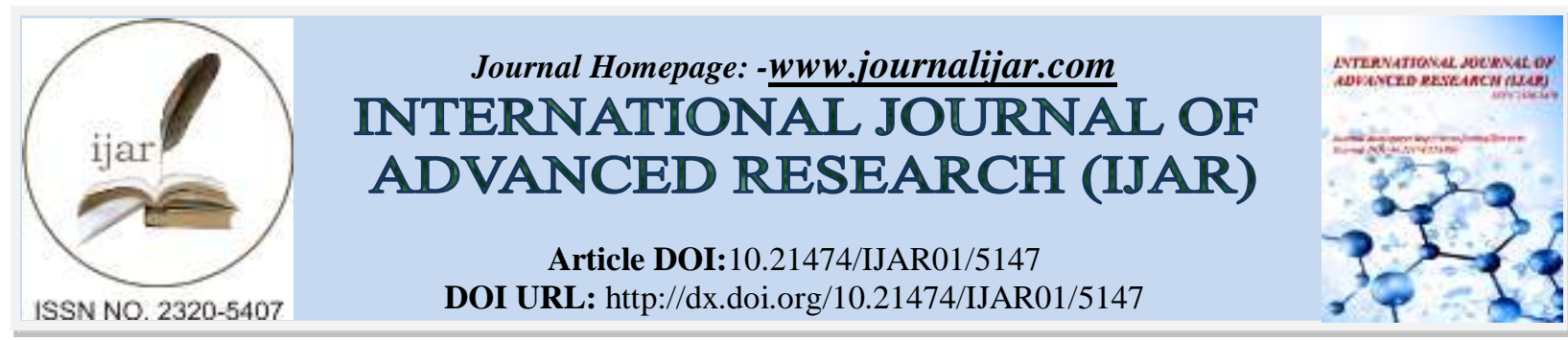

RESEARCH ARTICLE

\title{
A PHYTOSOCIOLGICAL CASE STUDY OF SOME WEEDS ASSOCIATED WITH CROP SESAME (SESAMUM INDICUM L.) IN THE SEMI ARID REGION OF NORTH-WESTERN DESERT OF RAJASTHAN.
}

Dr. Pankaj Swami ${ }^{1}$, Dr. Shamindra Saxena ${ }^{2}$ and Dr. Surendra Kumar Godara ${ }^{3}$.

1. Department of Botany Govt. Dungar College, Bikaner.

2. Department of Botany Govt. Dungar College, Bikaner.

3. Assistant Registrar, MGSU, Bikaner (Rajasthan).

\section{Manuscript Info}

Manuscript History

Received: 12 June 2017

Final Accepted: 14 July 2017

Published: August 2017

Key words:-

Phytosociolgy, weeds, Relative frequency, Relative density, Relative biomass Relative importance value (RIV), DS (days after sowing).

\begin{abstract}
Weeds are excellent examples of successful struggle for existence. Weeds are adapted by their abundant seed production, dispersal, varied seed dormancies, high competitive potentiality and ability to spread rapidly. Weeds have unique potentialities for adaptation; they thrive in almost any environment and adjust themselves to the changed conditions. Survival is difficult in arid region, where conditions are most inhospitable and impose severe constraints on plant life. Once a certain weed species is introduced, its abundance or scarcity is determined largely by the degree of competition offered by the crop and the prevailing environment. In agro-ecosystem weeds are harmful because they interfere with agricultural operations, which increase labour, compete with crop for water, nutrients, space, soil, light etc., and finally reduce the crop yield. Not only this, weeds have enormous seed production, variety of seed dormancies, first to grow and multiply under stress conditions and power of vegetative multiplication. They show rapid spreading and a deep penetrating root system, resist drought, start flowering and fruiting much earlier than crop and finally produce seeds to continue their progeny. Weeds not only rob the crops of nutrients but also the moisture which is most important ingredient in rain fed cropping. In present study the crop weed association was composed of 22 species. High frequency percent was shown by Tribulusterrestris. Farestiahamiltonii, Tribulusalatus. The relative biomass of crop and weeds were somewhat in proportion to relative densities. The net production of crop was higher than that of weeds. The period between 30 to 60 days after sowing was most critical stage for crop weed competition.
\end{abstract}

Copy Right, IJAR, 2017,. All rights reserved.

\section{Introduction:-}

Agriculture is the process of managing plant communities to obtain useful materials from the small set of species we call crops. Weeds comprise the "other" set of plant species found in agro-ecosystems. Although they are not intentionally sown, weed species are well adapted to environments dominated by humans and have been associated with crop production since the origins of agriculture. The ecological role of weeds can be seen in very different ways, depending on one's perspective. Most commonly, weeds are perceived as unwanted intruders into agro- 
ecosystems that compete for limited resources, reduce crop yields, and force the use of large amounts of human labor and technology to prevent even greater crop losses. In agro-ecosystem weeds are harmful because they interfere with agricultural operations, which increase labour, compete with crop for water, nutrients, space, soil, light etc., and finally reduce the crop yield. Not only this, weeds have enormous seed production, variety of seed dormancies, first to grow and multiply under stress conditions and power of vegetative multiplication. They show rapid spreading and a deep penetrating root system, resist drought, start flowering and fruiting much earlier than crop and finally produce seeds to continue their progeny. Weeds are plants growing where it is not desired or plants out of place (Kassasian, 1971) or any plant not sown in the field by farmer (Vaidya, et al., 1978) or uninvited plants in agro-ecosystem.

\section{Materials and Method:-}

Phytosociological studies were undertaken in general sowing at field of sesame in the year 2016 only by quadrate method (Tripathi and Misra, 1971) and the variety of sesame grown was RT 46. The size of quadrate had been $1 \mathrm{~m}$ sq (Pandeya and Saha, 1966) as determined by species-area curve method (Braun-Blanquet, 1932; Misra, 1968). 4 Quadrates were taken by random sampling and studied at site in year 2016 of kharif season after first shower in the month of July. Research site was located in crop field of sesame at village Ridmalsar lying $20 \mathrm{~km}$ in North-east to the city Bikaner and each quadrate was observed for density, frequency and biomass.

In each quadrate frequency, density and biomass of weeds and crop plants were recorded. Quadrates at site at each observations date have been clipped at the base and brought to laboratory in polythene bags. Then the harvest was separated species wise. The harvest had been dried in oven at $80{ }^{\circ} \mathrm{C}$ till constant weight and weighed to obtain aboveground biomass per $\mathrm{m}$ sq. or per quadrate. Such studies were started from two week after sowing i.e. on $15^{\text {th }}$, $30^{\text {th }}, 45^{\text {th }}, 60^{\text {th }}$, and $75^{\text {th }}$ days. The relative frequency, relative density, relative biomass and relative importance value (RIV) were calculated with the help of following expressions -:

$$
\begin{aligned}
& \text { Relative frequency }=\frac{\text { No.of occurence of species }}{\text { No. of occurence of all species }} \times 100 \\
& \text { Relative density }=\frac{\text { No.of occurence of species }}{\text { No. of occurence of all species }} \times 100 \\
& \text { Relative density }=\frac{\text { No.of occurence of species }}{\text { No. of occurence of all species }} \times 100
\end{aligned}
$$

RIV = Relative frequency + Relative Density + Relative biomass.

The phytograms of crop and weeds were plotted (fig no.1and 2). The mean data have been presented in table 1.

\section{Result and Discussion:-}

The crop-weed associations have been decomposed of following weed: species Tribulus terrestris Linn. Cenchurus biflorus Roxb, Cynodon dactylon (Linn.) pers., Farsetia Hamiltonii Royle., Trianthema portulacastrum Linn, Cenchrus cillaris Linn. Tribulus alatus Delike. Aristda Funiculata Trin. et Rupr., Chorchorus fasicularis (Linn.) Christensen, Indigofera cordifolia Heyene ex Roth, I. linifolia (Linn.F.) Retz., Ipomea pestgigridis Linn., Boerhavia diffusa Linn., Convolvulus pluricaulis, Mollugo lotodies, Euphorbia hirta Linn., Areva pseudo tomentosa Linn., Crotolaria burhia Buch-Ham., Elusine compressa L., Cleome Brachycarpa Vahl., Leptadenia pyrotechnica (forsk) Decne., Cleome viscosa L., Heliotropium Indicum Linn., Ziziphus nummularia (Burm.F.) Wight \& Arn., Digerium muricata Linn., Amaranthus spinosus Linn., Lasirus sindicus Linn., Citrulus colocynthis (Linn.) Schrad, Capparis spinosus Linn.

The maximum numbers of weeds were present on $45^{\text {th }}$ and $60^{\text {th }}$ days after sowing and minimum on $15^{\text {th }}$ day after sowing. It seems that the competition at the time of germination was insignificant which could not affect the crop at its initial stage. A few weed Tribulusterrestris, Cenchrusbiflorus and Farsetiahamiltoni have been found on $15^{\text {th }}$ day after the sowing and remained in an agro-ecosystem for the entire period of crop growth.

Tribulusterrestris, Farsetiahamiltoni, Ipomeapestgridis, Crotolariaburhia and Elusinecompressa have been regularly dispersed and Trianthemaportulacastrum, Indigoferalinifolia and Cleome brachycarpa have been irregularly dispersed. The above ground biomass of the crop plants (sesame) increased with growth till harvest. The total above 
ground biomass of weeds also increased with growth, however, the value of the latter have been lower than those of crop plants at all the stages of growth. The above ground biomass has not been in proportion of frequency of weeds.

The relative biomass of crop (85.05\%) and weed (14.94\%) has been in proportion of relative densities at $15^{\text {th }}$ days after sowing at the site. But there after the relative above ground biomass has not been in proportion of relative density or relative frequency of either the crop or the weeds.

Table 1:- Relative importance value of crop (Sesame) and associated weeds in agro-ecosystem

\begin{tabular}{|c|c|c|c|c|c|c|c|c|}
\hline $\begin{array}{c}\text { Days } \\
\text { after } \\
\text { sowing }\end{array}$ & \multicolumn{2}{|c|}{$\begin{array}{c}\text { Relative } \\
\text { Frequency }\end{array}$} & \multicolumn{2}{|c|}{$\begin{array}{l}\text { Relative } \\
\text { Density }\end{array}$} & \multicolumn{2}{|c|}{$\begin{array}{l}\text { Relative } \\
\text { Biomass }\end{array}$} & \multicolumn{2}{|c|}{ RIV } \\
\hline DS & CROP & WEED & CROP & WEED & CROP & WEED & CROP & WEED \\
\hline 15 & 47.61 & 52.37 & 84.96 & 15.02 & 85.05 & 14.94 & 72.54 & 27.44 \\
\hline 30 & 17.54 & 81.96 & 49.01 & 47.77 & 53.81 & 46.18 & 40.12 & 58.63 \\
\hline 45 & 10.41 & 89.67 & 28.86 & 67.33 & 53.21 & 46.78 & 30.82 & 67.90 \\
\hline 60 & 10.10 & 90.13 & 23.09 & 76.85 & 68.85 & 31.14 & \begin{tabular}{|l|}
37.38 \\
\end{tabular} & 66.04 \\
\hline 75 & 15.38 & 84.53 & \begin{tabular}{|c|}
30.17 \\
\end{tabular} & 69.73 & 78.89 & 21.70 & 41.28 & 58.65 \\
\hline
\end{tabular}

RIV gives a clear picture about the dominance of species. The RIV of crop has been maximum $(72.54 \%)$ in $15^{\text {th }}$ DS and minimum (30.82 \%) in $45^{\text {th }}$ DS. RIV of crop shows a sharp decrease from $15^{\text {th }}$ DS $(72.54 \%)$ to $30^{\text {th }}$ DS $(40.12$ $\%$ ) and gradual decrease up to $45^{\text {th }}$ DS and then slow increase (table 1). The almost same trend has been shown by relative biomass. It reflexes that there had been maximum crop-weed competition at $45^{\text {th }} \mathrm{DS}$ and minimum at $15^{\text {th }}$ DS; it means competition increases with increase of growth. The late increase of crop weed competition might be due to the late and periodic germination of many weeds (Koller 1961, Thurston 1960). The decrease of crop weed competition after $45^{\text {th }}$ DS might be due to early completing of life cycle by weeds or environment had not been congenial for their growth.

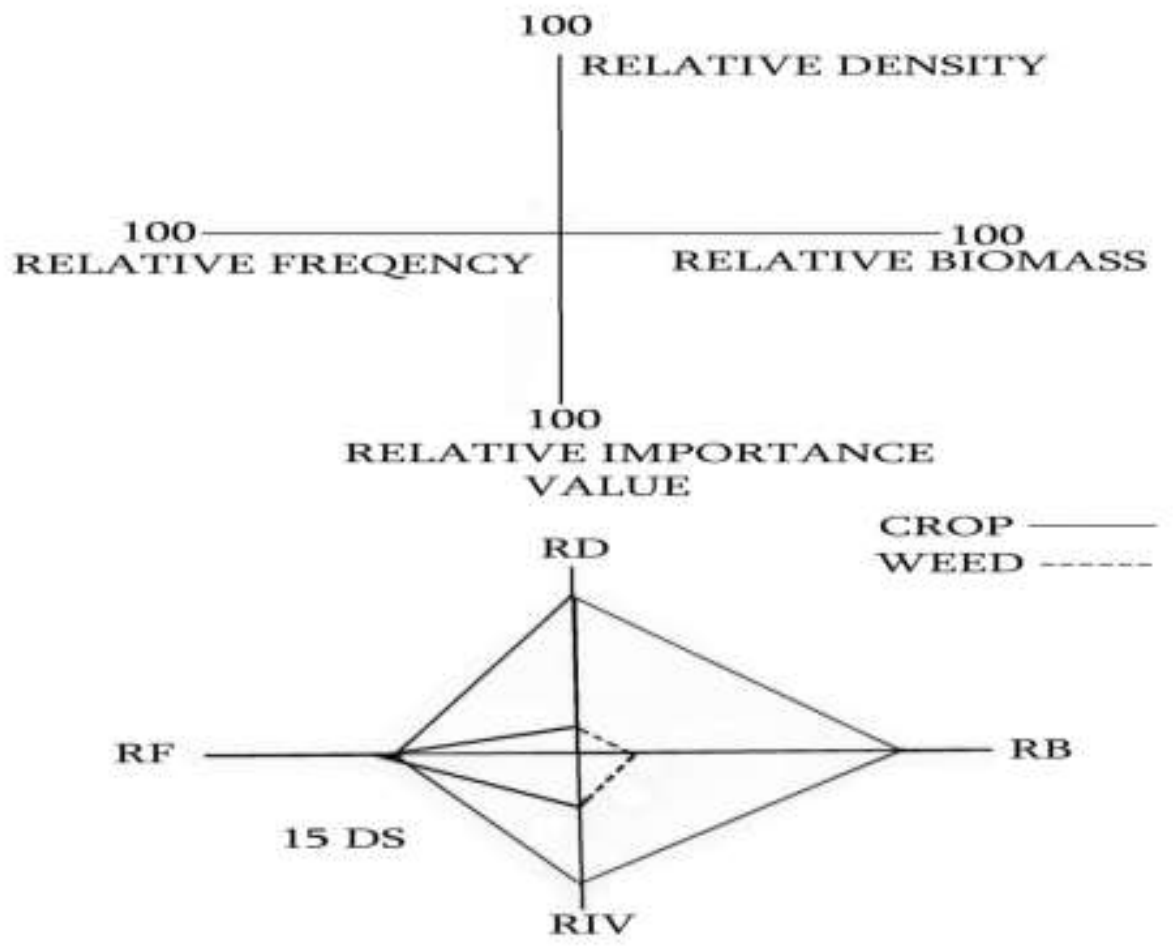

PHYTOGRAM AT 15 DS (Fig no. 1) 


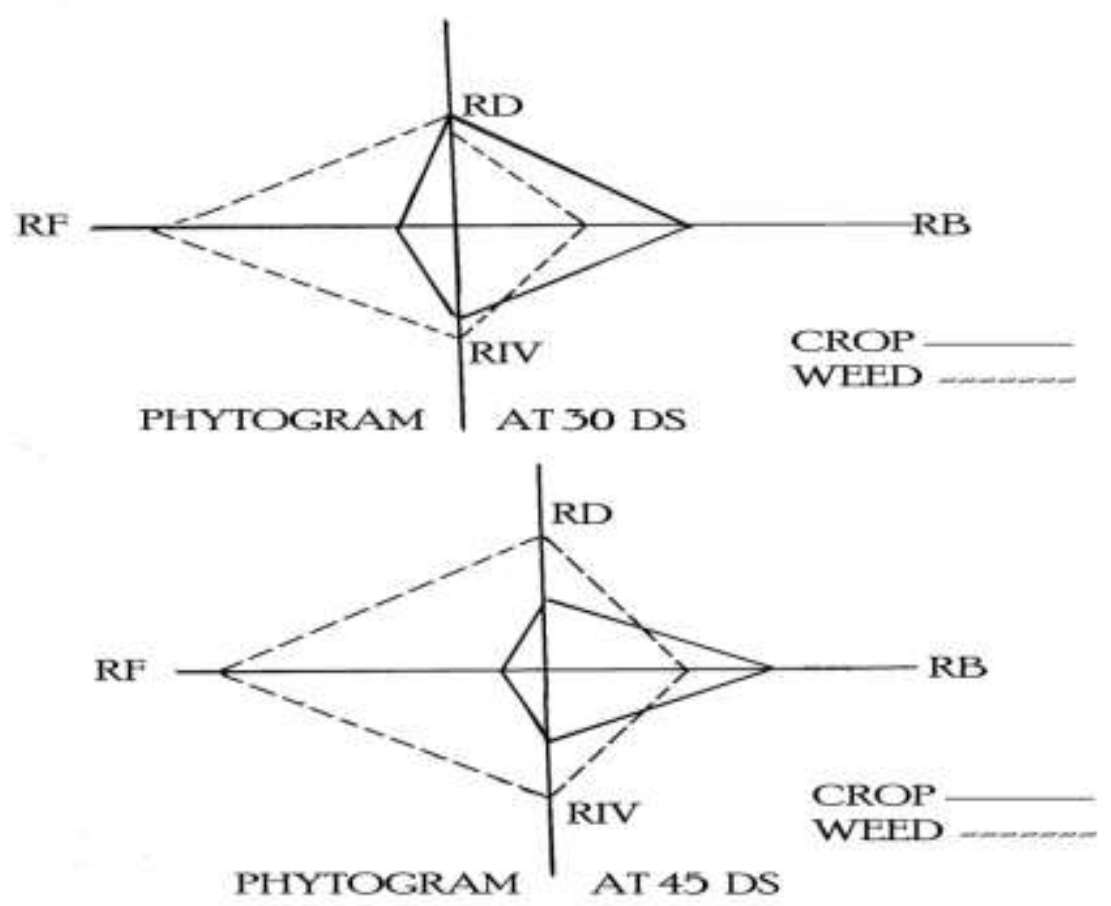

PHYTOGRAM AT 30 AND 45 DS (Fig no. 2)

\section{Conclusion:-}

The present study reveals that phytosociolgical study is of immense importance in context to arid zone farming and also helps to understand the phenomenon of improving the yield of particular crops. In present study the crop weed association was composed of 22 species. High frequency percent was shown by Tribulusterrestris. Farestiahamiltonii, Tribulusalatus. The relative biomass of crop and weeds were somewhat in proportion to relative densities. The net production of crop was higher than that of weeds. The period between 30 to 60 days after sowing was most critical stage for crop weed competition.

\section{References:-}

1. Braun Blanquet, J., 1932. Plant Sociology. Trans. rec. and ed. by G.D. Fuller and H.S. Conard. MC. Millan Book Co., New York.

2. Kasasian, L., 1971. Weed control in Tropics. Leonard Hill, London.

3. Koller, D., 1961: Ecological problem of seed dormancy. Cytobiotic stages in biological system (Ed. N. Growssowiez). Elservier publishing co. Amesterdam: 159-164.

4. Misra, R., 1968. .Ecology work book. Oxford \& IBN Publishing Co., New Delhi.

5. Pandeya, S.C. and Saha, D.P., 1966. Phytosociology and seasonal weed succession of paddy field and a comparison there of with adsoiningabandonend available land at Raipur (M.P.) Proc. Nat. Acad. Sci. India 36: 190-196.

6. Tripathi, R.S. and Misra R., 1971. Phytosociological studies of the crop weed association at Varanasi. J. Indian bot. Soc. 50: 42- 52.

7. Vaidhya, V.G., Sahasrabuddhe, K.R. and Kusape, V.S., 1978. Crop production and field experiments. Publisher A.A. Kulkarni, Vijaynagar, Pune. 